\title{
Climate change leads to increasing population density and impacts of a key island invader
}

\author{
Gregory T. W. McClelland, ${ }^{1,8}$ Res Altwegg, ${ }^{2,3}$ Rudi J. van Aarde, ${ }^{4}$ Sam Ferreira, ${ }^{4,5}$ \\ Alan E. Burger, ${ }^{6}$ And Steven L. Chown ${ }^{7}$ \\ ${ }^{1}$ Department of Botany and Zoology, Centre for Invasion Biology, Stellenbosch University, Matieland, South Africa \\ ${ }^{2}$ Department of Statistical Sciences, Centre for Statistics in Ecology, Environment and Conservation, University of Cape Town, \\ Private Bag X3, Rondebosch 7701 South Africa \\ ${ }^{3}$ African Climate and Development Initiative, University of Cape Town, Private Bag X3, Rondebosch 7701 South Africa \\ ${ }^{4}$ Conservation Ecology Research Unit, Department of Zoology and Entomology, University of Pretoria, Hatfield, \\ Pretoria 0083 South Africa \\ ${ }^{5}$ Scientific Services, SANParks, Kruger National Park, South Africa \\ ${ }^{6}$ Department of Biology, University of Victoria, Victoria, British Columbia V8W $3 N 5$ Canada \\ ${ }^{7}$ School of Biological Sciences, Monash University, Victoria 3800 Australia
}

\begin{abstract}
The considerable threats of invasive rodents to island biodiversity are likely to be compounded by climate change. Forecasts for such interactions have been most pronounced for the Southern Ocean islands where ameliorating conditions are expected to decrease thermal and resource restrictions on rodents. Firm evidence for changing rodent populations in response to climate change, and demonstrations of associated impacts on the terrestrial environment, are nonetheless entirely absent for the region. Using data collected over three decades on sub-Antarctic Marion Island, we tested empirically whether mouse populations have changed through time and whether these changes can be associated significantly with changing abiotic conditions. Changes in invertebrate populations, which have previously been attributed to mouse predation, but with little explicit demographic analysis, were also examined to determine whether they can be associated with changing mouse populations. The total number of mice on the island at annual peak density increased by $430.0 \%$ between $1979-1980$ and 2008-2011. This increase was due to an advanced breeding season, which was robustly related to the number of precipitation-free days during the non-breeding season. Mice directly reduced invertebrate densities, with biomass losses of up to two orders of magnitude in some habitats. Such invertebrate declines are expected to have significant consequences for ecosystem processes over the long term. Our results demonstrate that as climate change continues to create ameliorating conditions for invasive rodents on sub-Antarctic islands, the severity of their impacts will increase. They also emphasize the importance of rodent eradication for the restoration of invaded islands.
\end{abstract}

Key words: biological invasions; climate warming; insect conservation; islands; Mus musculus; rodents.

\section{INTRODUCTION}

Biological invasions pose one of the most significant threats to island biodiversity. They have resulted in the extinction of many species and the wholesale transformation of entire ecosystems (Courchamp et al. 2003, Blackburn et al. 2004, Simberloff et al. 2013). As the pace of climate change has begun to accelerate (IPCC 2013), so too has it become clear that the direct impacts thereof are likely to have profound consequences for many island systems (Ingram and Dawson 2005, Fordham and Brook 2008). Moreover, it has also been suggested that climate change will exacerbate the effects of many invasive species, so further impacting both diversity and ecosystem functioning (Walther et al. 2009).

Manuscript received 31 August 2017; accepted 2 October 2017. Corresponding Editor: Jacob R. Goheen.

${ }^{8}$ E-mail: mcclellandgreg@gmail.com
Commensal rodent species rank among the most significant island invaders. They have colonized at least $90 \%$ of the world's archipelagos (Towns et al. 2006) and have been responsible for numerous extinctions and large population declines of avifauna, invertebrates, and plants (Jones et al. 2008, Athens 2009, St Clair 2011). Even species such as house mice (Mus musculus), initially thought unable to impact larger prey, pose a considerable conservation threat to seabirds, including species as large as the Tristan Albatross (Diomedea dabbenena; Wanless et al. 2009). Rodents have also been shown to have considerable indirect effects on ecosystem functioning (Fukami et al. 2006, Kurle et al. 2008). Several predictions have been made that these considerable impacts of rodents are likely to be compounded by climate change, especially in systems where rodents may be constrained by an interaction between severe climate and food limitation (Berry 1968, Berry et al. 1979). Climate change is likely to influence both thermal and resource restrictions on rodents. 
Given the relationship between temperature and development rate in ectotherms, warming temperatures have the potential to increase prey populations by alleviating the thermal constraints of development and reproduction for many invertebrate species (Honêk 1996, Deutsch et al. 2008). In a similar manner, increases in prey resources in addition to ameliorating temperatures are likely to enhance rodent survival, depress the metabolic costs of thermoregulation, and allow rodents to divert more resources to reproduction (Singleton et al. 2005, Bronson 2009). In turn, it is expected that rodents may be capable of substantially depressing the populations of favored prey species.

Forecasts for such interactions have been most pronounced for the sub-Antarctic islands of the Southern Ocean (Smith and Steenkamp 1990). Indeed, it has been argued that rodents pose the most significant current and future threats to conservation in the region (Frenot et al. 2005). There is, however, no firm evidence in this region that rodent populations have been affected by climate change, or are significantly correlated with changing prey populations. While inferences have been drawn from short-term data (Chown and Smith 1993, van Aarde et al. 1996), and longer-term assessments of traits (Treasure and Chown 2014), population-based assessments are missing. Given this situation and the conservation significance of these islands (de Villiers et al. 2006), here we test directly these ideas using long-term data sets on the populations of mice and their invertebrate prey from sub-Antarctic Marion Island. In particular, we determine whether mouse populations across a range of significant habitats have changed through time and whether these changes can be associated with changing abiotic conditions. We then examine whether changes in invertebrate populations, which have previously been attributed to mouse predation, but with little explicit demographic analysis (Crafford and Scholtz 1987, Chown and Smith 1993), can be associated with changing mouse populations, which we also show, remain major predators of invertebrates.

\section{Methods}

\section{Study area}

Sub-Antarctic Marion Island, South Africa (465ㄴ $\mathrm{S}$, $37^{\circ} 45^{\prime} \mathrm{E}$ ) has an oceanic climate (mean annual temperature $\sim 6.5^{\circ} \mathrm{C}$, total precipitation of $\sim 1,900 \mathrm{~mm}$ ), but is currently experiencing rapid climate change. Since 1947, mean annual temperature has increased by more than $1.8^{\circ} \mathrm{C}$ and precipitation has declined by more than $800 \mathrm{~mm}$ (le Roux and McGeoch 2008). The island is characterized by two biomes; polar desert above $650 \mathrm{~m}$ above sea level, and sub-Antarctic tundra below (Gremmen and Smith 2008). Five habitat complexes comprise the sub-Antarctic tundra biome; mire (wet peaty areas), slope (lowland areas with well-drained slopes), biotic (areas manured by seals and seabirds), saltspray (highly saline coastal herbfield), and fellfield (vascular plant cover dominated by cushions of Azorella selago).

Mice were likely introduced to Marion Island through sealing activity sometime after 1818 (Watkins and Cooper 1986). The first demographic studies of the species occurred in the late 1970s (Berry et al. 1978, Gleeson 1981) and focused in the three main habitats in which mice were found to live; mire, slope, and biotic. The timing of the breeding season varied between habitats and appeared correlated with invertebrate biomass, on which mice predominantly foraged. Populations peaked in austral summer and were followed by significant mortality in May/June (late summer/early winter). Domestic cats (Felis catus), present on Marion Island from 1949 to 1991, did not prey on mice to an extent that constrained the mouse population (van Aarde 1980). Moreover, cat abundances were reduced considerably following the release of feline panleucopaenia in 1977, and again with the commencement of a comprehensive eradication program in 1986-1987 (Bester et al. 2002). By 1992 they had been eradicated. While mice may have increased their summer densities, in addition to their elevational range, between 1979 and 1991 (Matthewson et al. 1994) the population size was thought to be relatively stable between 1991 and 2001 (Ferreira et al. 2006).

\section{Mouse density}

Live trapping was conducted in 1991-1992, 19931994, 1996-1997, 1998-1999, and 2008-1911. Trapping grids were placed within $1 \mathrm{~km}$ of the coastline in the mire, slope, and biotic habitats following Gleeson (1981). Trapping occurred for five successive nights to complete one trapping "session" (see Appendix S1: Table S1 for trapping session parameters). Mice were marked by toe clipping from 1991 to 1999 and by stainless numbered ear tags from 2008 to 2011.

Mice were sexed by anogenital distance, and mass was measured to the nearest $0.5 \mathrm{~g}$ (Pesola $50 \mathrm{~g}$ scale; Baar, Switzerland). Breeding status in female mice was assessed by the presence of a perforated vagina. Mice were separated into two age classes; juveniles $(\leq 12.5 \mathrm{~g}$, no perforated vagina in females) and subadult/adults $(\geq 13 \mathrm{~g}$ or perforated vagina in females) following Gleeson (1981). These two age classes were later combined for density estimation because many sessions had too few mice for accurate estimates when modeled separately.

Mouse density during each individual session was estimated using maximum-likelihood spatially explicit capture-recapture models (SECR; Borchers and Efford 2008). We fitted separate models for each month and habitat, pooling replicate trapping grids when available, because the SECR models are computationally intense and fitting the global model for the complete data set was not feasible. We assumed a random (Poisson) distribution of range centers with a negative exponential detection function parameterized by the probability of capture $(g 0)$ and range size $(\sigma)$. Even though this 
detection function suggests a positive detection probability for infinite distances, in practice distances are considered up to the point where they decline close enough to zero to have no further effect on the results. This distance is added as a buffer around the trapping array, which was set here to $300 \mathrm{~m}$, after verifying that results were insensitive to wider buffers. Removals in the population (i.e. accidental deaths during trapping) were assigned known capture histories of 0 with probability equals 1 following death.

Model selection was conducted using AIC and multimodel inference (Burnham and Anderson 2004) as well as visual inspection of the estimated parameters and standard errors for evidence of overparameterization and parameter non-identifiability (Gimenez et al. 2004). Analyses were limited to those models that had a $\triangle$ AIC of $<2$ (Burnham and Anderson 2002). All models were run in the statistical software R 2.15.0 (R Development Core Team 2010) and the package secr (Efford 2011). Differences in peak density estimates between years for each habitat were assessed using a Wald test, comparing to a standard normal distribution whereby $z$ values larger than 1.96 (critical value at $\alpha=0.05$ ) were considered significant.

The original mouse trapping data from 1979 to 1980 were unavailable for SECR modeling. Density estimates from Gleeson (1981) were used when referencing this time period. These estimates were based on a modified Petersen Index, with assessment lines to estimate the area of effect, and are likely overestimates of true density (Borchers and Efford 2008). We confirmed this by comparing our SECR density estimates for 1991-1992, our only capture data where assessment lines were also used, with estimates obtained using the Petersen Index method (Matthewson et al. 1994). When compared to SECR, Petersen Index estimates had an average 25.8\% positive bias $(-16.0 \%$ to $65.7 \%, n=17)$ when densities were $>10$ individuals/ha and a $274.5 \%$ positive bias $(48.0 \%$ to $656.1 \%, n=9)$ when densities were $<10$ individuals/ha (Appendix S1: Table S2).

\section{Mouse phenology}

To test for shifts in mouse breeding phenology, the presence or absence of juvenile mice in the trappable population was used. Previous studies of Marion Island mice used the occurrence of pregnant females observed through dissection (Matthewson et al. 1994, Avenant and Smith 2004) for assessments of phenology. Poor environmental conditions do not, however, inhibit mice from attempting reproduction (Perrigo 1987). Thus, the ability of mice to successfully wean offspring is a more appropriate measure of breeding conditions and phenology.

To understand the likely effects of changing phenology on the mouse population, a three-age (weaned juvenile, subadult, and adult) periodic matrix projection model (Caswell 2001) was used (Appendix S2). In the model, juvenile mice become subadults after 4 weeks. Subadults have the same survival probability of adults but have yet to reach sexual maturity so do not breed until they become adults after 8 weeks. In brief, we examined the outcomes of breeding initiation such that juveniles would appear in February, January, and December, respectively, using the slope habitat in 1998-1999 as an example. We chose this data set because of the considerable change in phenology and peak density between 1998-1999 and 2008-2011 observed in this habitat. We parameterized the model using maximum likelihood estimates calculated for monthly mouse survival using a Cormack-JollySeber (CJS) open population model (Lebreton et al. 1992, Appendix S3). Reproductive rate and litter size were estimated from Matthewson et al. (1994).

\section{Climate analysis}

We compared changes in mouse density and phenology across years to test the hypothesis that weather directly influences mouse density and phenology, and therefore any observed increases are the direct result of ameliorating climate conditions. Much of the biotic habitat in the study sites has transitioned from Poa cookii tussock, which is highly favorable to rodents (Pye et al. 1999), to invasive $P$. аппиа lawn over the course of the study, a continuing effect of disturbance by growing fur seal populations (Haussmann et al. 2013). Therefore, analyses were limited to the slope and mire habitats to avoid the potentially confounding effects of this vegetational shift.

To examine climate effects on mouse density, we compared densities in winter (late August to early September), spring (late October to early November), and summer (late January to early February) under seasonal weather conditions across years. For years and habitats where multiple grids were trapped, we estimated densities on individual grids separately using SECR. Tested weather variables were total precipitation, mean daily temperature, and the number of precipitation-free days over a 12-week period prior to each trapping date (the data did not differentiate between rain and snowfall). All variables were standardized to a mean of zero and unit variance, and the collinearity among them was first tested with variance inflation factors (VIF). Because density values are estimates rather than data, and so come with a standard error, we adopted a Bayesian approach similar to that of McCarthy and Masters (2005). The basic structure of the model was similar to a regular linear mixed effects model with climate variables, season, and habitat as fixed effects, year and grid as random effects, and normally distributed residuals. We modeled densities as originating from a normal distribution using the density and standard errors estimated by the SECR analysis. We used non-informative priors (Normal $\left.\left(0,10^{7}\right)\right)$ for density, climate, seasonal, and habitat effects, and Uniform $(0,100)$ for the standard deviation of the grid and year effects. We then ran three Markov Chain Monte Carlo chains of 40,000 iterations, discarding the first 20,000 as burn-in. The Gelman-Rubin diagnostic 
indicated that these models converged quickly and all $R$ hat values were below 1.01. All analyses were performed using the software JAGS 4.2.0 called from program $\mathrm{R}$ via the package rjags (Plummer et al. 2016).

We also tested if weather conditions during the prebreeding season (1 May to 30 September) were correlated with mouse phenology. We used the appearance of the first juvenile on trapping grids as an indicator of phenology. Because trapping dates will dictate phenology dates to a certain extent, we chose to use a simple partial Pearson correlation analysis, controlling for habitat. We tested each weather variable used in the density analysis separately.

\section{Diet analysis}

To document current mouse diet, mice were snaptrapped every 8 weeks in 2008-2011. Following the previous methods of Smith et al. (2002), at least 15 baited snap-traps were deployed ad hoc at sunset and retrieved after 1-3 $\mathrm{h}$ to minimize cannibalization of trapped mice. Trapping occurred in all three aforementioned habitat types on both the eastern and western sides of the island. Snap-trapped areas were at least $1 \mathrm{~km}$ distant from livetrapped grids. Stomach content analysis followed the general methodology of Smith et al. (2002), with diet variety and diet diversity calculated following Ebersole and Wilson (1980). The relative importance value (RIV) of each item was calculated following Cooper and Skinner (1979; Appendix S4).

\section{Invertebrate biomass}

Invertebrates were sampled in 1976-1977 (Burger 1978), 1996-1997 (Hanel 1999), and 2006-2007 as part of a long-term assessment. Soil cores (Appendix S5) were taken in the seven vegetation types that comprise the majority of the three habitats in which mice occur; Sanionia uncinatus, Blepharidophyllum densifolium, and Jamesoniella colorata mires, Blechnum penna-marina and Acaena magellanica slopes, and Cotula plumosa and Poa cookii biotic areas.

Analyses were limited to the macroinvertebrates that formed the major components of the mouse diet, pooled into five groups to match the taxonomic resolution of the original survey (Burger 1978). The prey groups were lepidopteran larvae (Pringleophaga marioni and Embryonopsis halticella, of which the latter are generally rare in core samples owing to their monophagy of Poa cookii), weevil larvae (Curculionidae), weevil adults, soil worms (potworms and earthworms; Enchytraeidae and Microscolex kerguelarum), and spiders (Myro spp., Prinerigone vagans).

Differences in invertebrate biomass between sampling years were examined using a Kruskal-Wallis one-way analysis by ranks after Shapiro-Wilk Normality Tests rejected the assumption of normal distribution. Next, a two-part conditional modeling approach, where the occurrence of zero observations and the positive abundances are separately modeled to account for zeroinflated data, was used to test for impacts of environmental variables on bimonthly estimates of invertebrate biomass. The first part is a binary outcome logistic-type model ("presence") and the second part is a truncated log-normal distribution model ("biomass given presence") (Welsh et al. 1996) calibrated on available data. The predictor variables in both the "presence" and "biomass given presence" models were average seasonal mouse density, average temperature for the previous $30 \mathrm{~d}$, total precipitation for the previous $30 \mathrm{~d}$, and season (winter, May-October; summer, November-April) after being assessed for collinearity with the VIF and Pearson correlation matrix. We created models for each invertebrate group in each vegetation type (See Appendix S1: Table S3 for a single model analysis). All combinations of predictor variables were modeled and ranked by $\mathrm{AIC}_{\mathrm{c}}$. A relative importance value (RIV) for each variable was calculated by summing the Akaike weight $\left(w_{\mathrm{i}}\right)$ of every model in which it was included. The resulting values ranged from 0 to 1 , with values closer to 1 indicating greater importance.

The logistic and ordinary regression models examining the relationship between invertebrate biomass and mouse density (biomass $\sim$ mouse density) were then combined to model the expected invertebrate biomass in relation to mouse density following the method set out by Fletcher et al. (2005; Appendix S6).

\section{RESUlts}

\section{Mouse density}

Population fluctuations increased in amplitude between 1979-1980 and 2008-2011 (Appendix S1: Table S4). Peak summer density in the mire habitat increased twofold between 1993-1994 and 1998-1999 (Fig. 1a). The highest estimated density in 2008-2011 (231.8 mice/ha, 95\% CI 159.6-336.5) was significantly higher than the highest density in 1998-1999 (126.9 mice/ha, 95\% CI 90.4-178.4, Wald $=2.11, P=0.03$ ). Peak density in the slope habitat remained constant from 1991-1992 to 1998-1999, but increased fourfold between 1998-1999 (50.1 mice/ha, 95\% CI 35.2-71.2) and 2008-2011, peaking at $210.1 \mathrm{mice} / \mathrm{ha}$ $(95 \%$ CI $160.7-274.6$, Wald $=5.30, P<0.001)$ in 2010 . Peak density in the eastern biotic trapping grid was highest in 1991-1992 (249.0 mice/ha, 95\% CI 195.3-317.6), declined significantly in the mid and late 1990s, and significantly increased again between 1998-1999 (118.2 mice/ ha, 95\% CI 74.6-187.2) and 2008-2011 (222.4 mice/ha, 95\% CI 181.5-272.5, Wald $=2.86, P<0.01$ ). However, the late-summer/early-winter die-offs that characterized the Marion Island mouse population continued in 20082011, with winter densities higher or lower than those from the 1990s equally likely. 
a

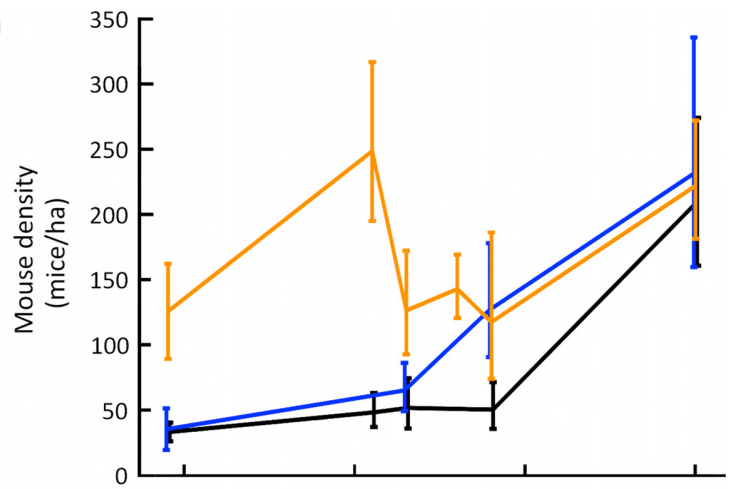

b

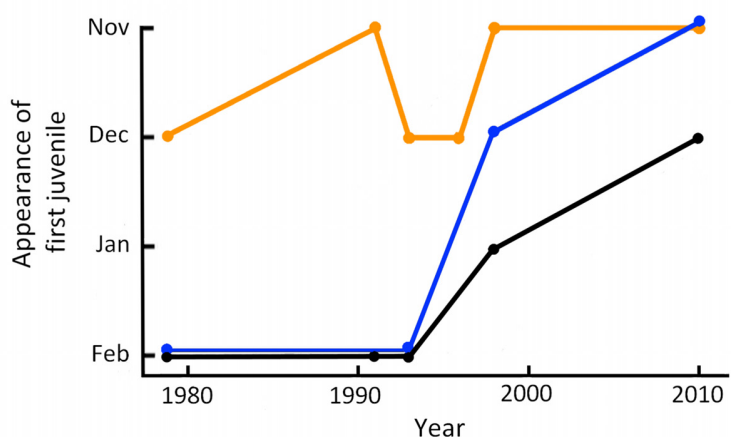

FIG. 1. (a) Estimated peak density of mice/ha (with $95 \%$ $\mathrm{CI}$ ) in the mire (blue), slope (black), and biotic (orange) habitats on Marion Island, 1979-2011. Estimates for 1996-1997 and 1998-1999 were each pooled across replicates. Estimates for 1979-1980 were based on a modified Petersen Index and are likely an overestimate of true density, whereas the other estimates were based on spatially explicit capture recapture methods and likely unbiased. (b) First appearance of juvenile mice in the trappable population in the mire (blue), slope (black), and biotic (orange) habitats on Marion Island, 1979-2011. Circles indicate years in which trapping occurred. [Color figure can be viewed at wileyonlinelibrary.com]

\section{Mouse phenology}

A shift toward earlier breeding occurred in the Marion Island mouse population between 1979-1980 and 20082011 (Fig 1b). Breeding phenology remained constant between 1979-1980 and 1993-1994 in the mire and slope habitats, advancing thereafter, most prominently in the mire habitat. The breeding season in the biotic habitat showed more variation, with juvenile appearance varying from December to November. Mice appeared to stop breeding in all habitats in late March or early April throughout the study period, estimated from when juveniles stopped appearing in traps and accounting for 6 weeks required for gestation and weaning (Berry 1970). The matrix model estimated that in the absence of change to any other demographic parameter, the advancement of the breeding season from February (here, referring to the month in which juvenile mice first appear in traps) to January could explain the observed increase. Under this scenario, the model predicted increased numbers of juvenile and subadult/adult mice at peak density by $78.6 \%$ and $81.0 \%$, respectively (Fig. 2, Appendix S1: Table S5), for a total increase of $79.7 \%$. Initiating the breeding season in December resulted in the peak number of juvenile and subadult/adult mice increasing by $116.9 \%$ and $203.2 \%$, respectively, for a total increase of $159.4 \%$ from the original February start date.

\section{Climate impacts on mice}

We found no evidence that weather directly influenced mouse densities. The $95 \%$ credible interval of mean daily temperature $(2.48[-5.78$ to 11.58$])$, total precipitation $(-3.51[-6.99$ to 5.04$])$, and the number of precipitation-free days ( 0.48 [ -4.06 to 5.05$])$ clearly encompassed zero.

We found no evidence that temperature $(r=-0.14$, $P=0.71, \mathrm{df}=8)$ or total precipitation $(r=0.30, P=0.41)$ during the non-breeding season were related to observed changes in phenology. However, the number of precipitation-free days had a significant negative relationship with the first appearance date of juveniles $(r=-0.80$, $P=0.01)$, meaning juvenile mice appeared earlier in winters with more precipitation-free days.

\section{Mouse diet}

Mouse diet consisted primarily of invertebrates of which lepidopteran larvae had the highest mean annual RIV (Table 1). Between 1991-1992 and 2008-2011, the importance of lepidopteran larvae increased significantly in the mire habitat, while plant material significantly declined. The slope habitat had significant increases in the importance of lepidopteran larvae and spiders, with significant declines in weevil adults, larvae, and plant material. The importance of lepidopteran and weevil larvae increased in the biotic habitat, while weevil

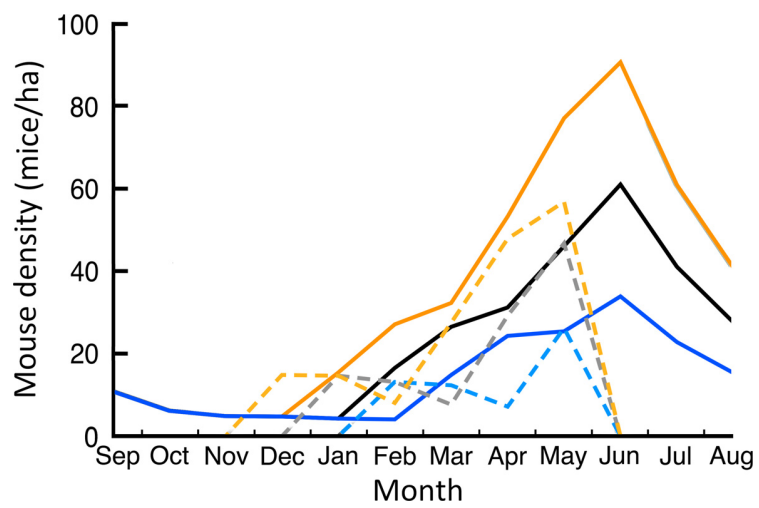

FIG. 2. Estimated impact of phenology in the Marion Island mouse population based on the matrix population model (Appendix S1: Table S5). Earlier breeding resulting in the first appearance of juvenile mice in December, January, and February is represented by orange, black/gray, and blue, respectively. Solid and dashed lines indicate the number of subadults/adults and juveniles, respectively. [Color figure can be viewed at wileyonlinelibrary.com] 
TABLE 1. Annual mean relative importance values (RIV) of diet items in the mire, slope, and biotic habitats on Marion Island in 1992-1993 and 2008-2011.

\begin{tabular}{|c|c|c|c|c|c|}
\hline Food item & 1992-1993 & 2008-2011 & df & $t$ & $P$ \\
\hline \multicolumn{6}{|l|}{ Mire } \\
\hline Lepidopteran larvae & $59.2 \pm 23.8$ & $74.0 \pm 18.9$ & 320 & 6.89 & $<0.001$ \\
\hline Weevil larvae & $8.1 \pm 12.5$ & $8.0 \pm 7.7$ & 320 & 0.04 & 0.970 \\
\hline Weevil adults & $8.1 \pm 6.5$ & $4.8 \pm 7.0$ & 320 & 1.47 & 0.146 \\
\hline Soil worms & $2.1 \pm ? ? \dagger$ & $1.6 \pm 1.9$ & 320 & & NA \\
\hline Spiders & $0.7 \pm ? ?$ & $6.9 \pm 1.6$ & 320 & & NA \\
\hline Plants & $15.7 \pm 2.1$ & $1.7 \pm 1.8$ & 320 & 4.10 & $<0.001$ \\
\hline Unknown vertebrate & 0.0 & $1.5 \pm 2.1$ & 320 & & NA \\
\hline Other prey & $5.9 \pm ? ?$ & $1.6 \pm 3.5$ & 320 & & NA \\
\hline Mean diet variety & $8.2 \pm 0.7$ & $2.3 \pm 0.3$ & 320 & 100.77 & $<0.001$ \\
\hline Mean diet diversity & $2.8 \pm 0.2$ & $3.6 \pm 0.3$ & 320 & -19.23 & $<0.001$ \\
\hline \multicolumn{6}{|l|}{ Slope } \\
\hline Lepidopteran larvae & $11.8 \pm 15.2$ & $50.4 \pm 31.5$ & 290 & -13.85 & $<0.001$ \\
\hline Weevil larvae & $12.0 \pm 16.1$ & $4.0 \pm 3.4$ & 290 & 3.07 & 0.003 \\
\hline Weevil adults & $20.0 \pm 16.8$ & $1.6 \pm 1.8$ & 290 & 6.00 & $<0.001$ \\
\hline Soil worms & $0.9 \pm ? ?$ & $2.8 \pm 5.7$ & 290 & & NA \\
\hline Spiders & $2.6 \pm 4.0$ & $6.1 \pm 8.4$ & 290 & -2.59 & 0.010 \\
\hline Plants & $48.4 \pm 33.9$ & $22.0 \pm 33.5$ & 290 & 13.56 & $<0.001$ \\
\hline Unknown vertebrate & 0.0 & $4.3 \pm 5.3$ & 290 & & NA \\
\hline Other prey & $4.5 \pm ? ?$ & $8.9 \pm 21.8$ & 290 & & NA \\
\hline Mean diet variety & $8.2 \pm 0.7$ & $2.4 \pm 0.6$ & 290 & 70.73 & $<0.001$ \\
\hline Mean diet diversity & $3.6 \pm 0.3$ & $3.0 \pm 0.9$ & 290 & 5.91 & $<0.001$ \\
\hline \multicolumn{6}{|l|}{ Biotic } \\
\hline Lepidopteran larvae & $45.1 \pm 21.3$ & $52.4 \pm 28.2$ & 424 & -2.12 & 0.036 \\
\hline Weevil larvae & $3.9 \pm 7.6$ & $16.7 \pm 19.4$ & 424 & -7.12 & $<0.001$ \\
\hline Weevil adults & $6.9 \pm 8.1$ & $0.3 \pm 0.4$ & 424 & 4.46 & $<0.001$ \\
\hline Soil worms & $9.2 \pm 19.9$ & $5.6 \pm 10.8$ & 424 & 1.91 & 0.06 \\
\hline Spiders & $0.4 \pm ? ?$ & $0.1 \pm 0.1$ & 424 & & NA \\
\hline Plants & $22.6 \pm 20.2$ & $20.7 \pm 18.8$ & 424 & 0.56 & 0.578 \\
\hline Unknown vertebrate & 0.0 & $3.3 \pm 3.5$ & 424 & & NA \\
\hline Other prey & $11.9 \pm ? ?$ & $0.9 \pm 2.1$ & 424 & & NA \\
\hline Mean diet variety & $11.6 \pm 0.6$ & $1.9 \pm 0.4$ & 424 & 161.45 & $<0.001$ \\
\hline Mean diet diversity & $4.4 \pm 0.3$ & $3.1 \pm 0.8$ & 424 & 12.55 & $<0.001$ \\
\hline
\end{tabular}

Notes: RIVs consist of frequency and volume of occurrence in the diet and sum to 100 per column. Mean diet variety and diversity are also presented. Values are mean \pm SD. Data from 1992 to 1993 were extracted from Smith et al. (2002). The "other prey" group refers to other species of invertebrates including mites, aphids, and flies. The "unknown vertebrate" group refers to mammal and/or avian tissue (muscle, adipose, etc.). NA = not applicable.

$\uparrow$ The data were presented in Smith et al. (2002) in such a way that it was not possible to extract standard deviation.

adults declined. While no vertebrate tissue was recorded in 1991-1992, it was common in all three habitats in 2008-2011. Because the majority of samples could not be identified as mammal or avian (based on the presence of hair or feathers), we combined all vertebrate tissue into a single category. However, it should be noted that of the samples that could be identified, $87.5 \%$ were avian $(n=8)$. Mouse diet variety decreased significantly in all habitats. Diet diversity declined significantly in the slope and biotic habitats, but increased significantly in the mire habitat between study periods.

\section{Invertebrate biomass}

The majority of invertebrate groups experienced significant $(P<0.05)$, and often very large declines (e.g., by as much as 197.6-fold between 1976-1977 and 20062007) in all seven measured vegetation types (Fig. 3a-e). The lack of a significant difference in weevil adult biomass in most vegetation types is likely due to the considerable variation in the data considering their decline to the point of non-detection in $S$. uncinatus, B. pennamarina, and P. cookii by 2006-2007. The only species group to have a significant increase in biomass after 1996-1997 was lepidopteran larvae in C. plumosa $(t=-3.62, \mathrm{df}=9.83, P<0.01)$.

Mouse density was the most important explanatory variable in terms of both invertebrate presence and biomass when the Akaike weight $\left(w_{i}\right)$ for each variable across all possible models for each species and habitat were summed (Appendix S1: Table S6), acknowledging the lack of mouse density estimates specific to invertebrate 

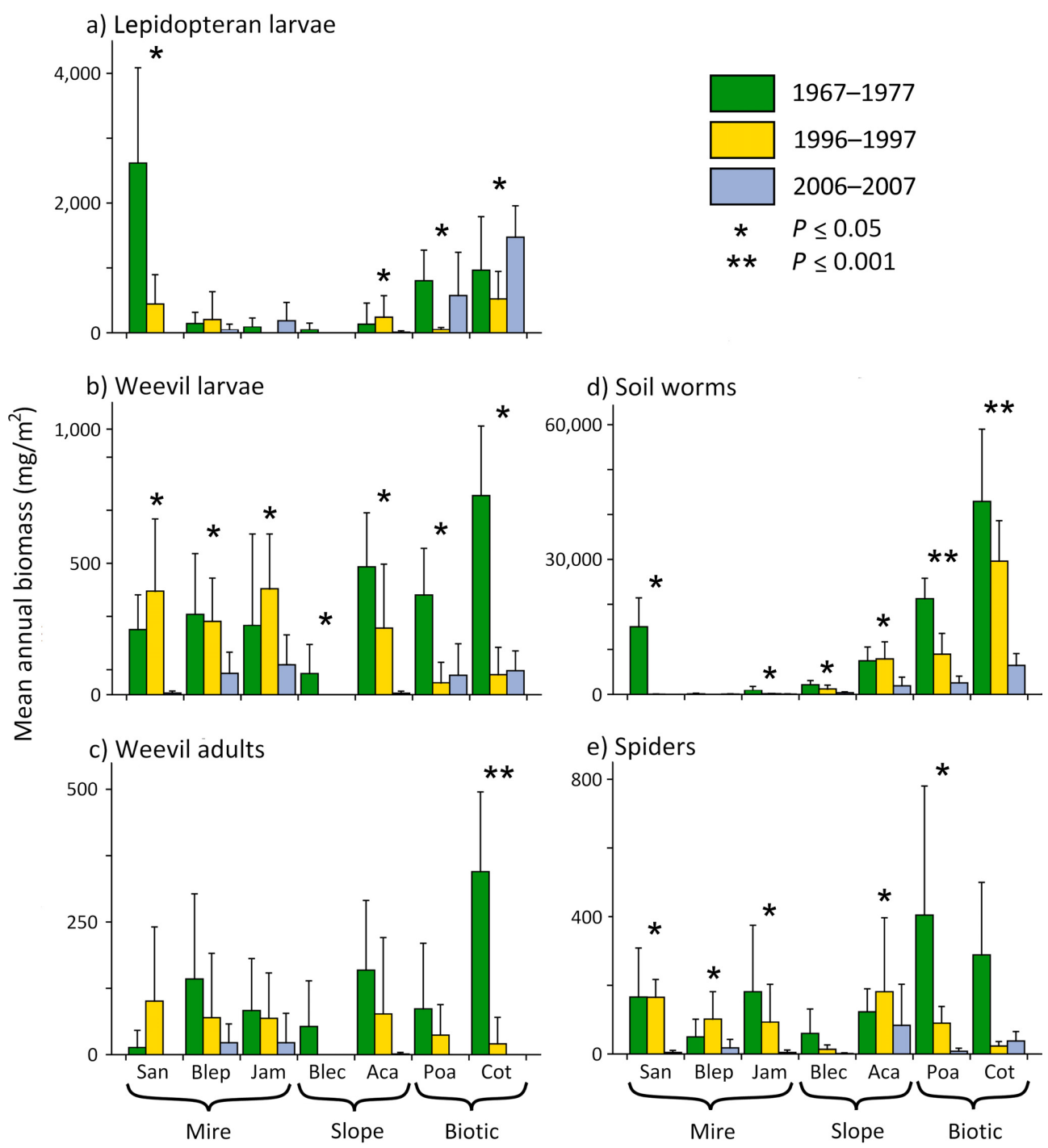

Vegetation type

FIG. 3. Annual biomass (mean $\pm \mathrm{SD}$ ) of (a) lepidopteran larvae, (b) weevil larvae, (c) weevil adults, (d) soil worms, and (e) spiders on Marion Island in 1976-1977, 1996-1997, and 2006-2007 in Sanionia uncinatus (San), Blepharidophyllum densifolium (Blep), Jamesoniella colorata (Jam), Blechnum penna-marina (Blec), Acaena magellanica (Aca), Poa cookii (Poa), and Cotula plumosa (Cot) vegetation. Stars indicate significant differences in invertebrate biomass between sampling periods. [Color figure can be viewed at wileyonlinelibrary.com]

sampling years. Mouse density had the highest relative importance values (RIV) in $51.6 \%$ of presence models, followed by season and temperature $(25.8 \%$, each), and precipitation $(6.5 \%)$. Invertebrate biomass was also best explained by mouse density, with the highest RIV in $58.1 \%$ of models, followed by precipitation (19.4\%), temperature $(12.9 \%)$, and season $(6.5 \%)$.

The relationship between mice and invertebrates predicted by the conditional models was highly dependent on habitat (Fig. 4). Biomass of all invertebrate species was predicted to decline in response to increased mouse density in the mire and slope habitats, with the exception of spiders in B. densifolium and lepidoteran larvae (presence only) in $J$. colorata. By contrast, invertebrate biomass was positively associated with mouse density in the biotic habitat.

\section{Discussion}

Despite decades of speculation that mice are increasing in density in the sub-Antarctic (Smith and Steenkamp 1990), this study provides the first demonstration that this is the case, at least on Marion Island. Adjusting for area, the total number of mice below 300 m elevation at peak density more than doubled between 1998-1999 and 2008-2011 (Table 2). Peak densities in the slope and 


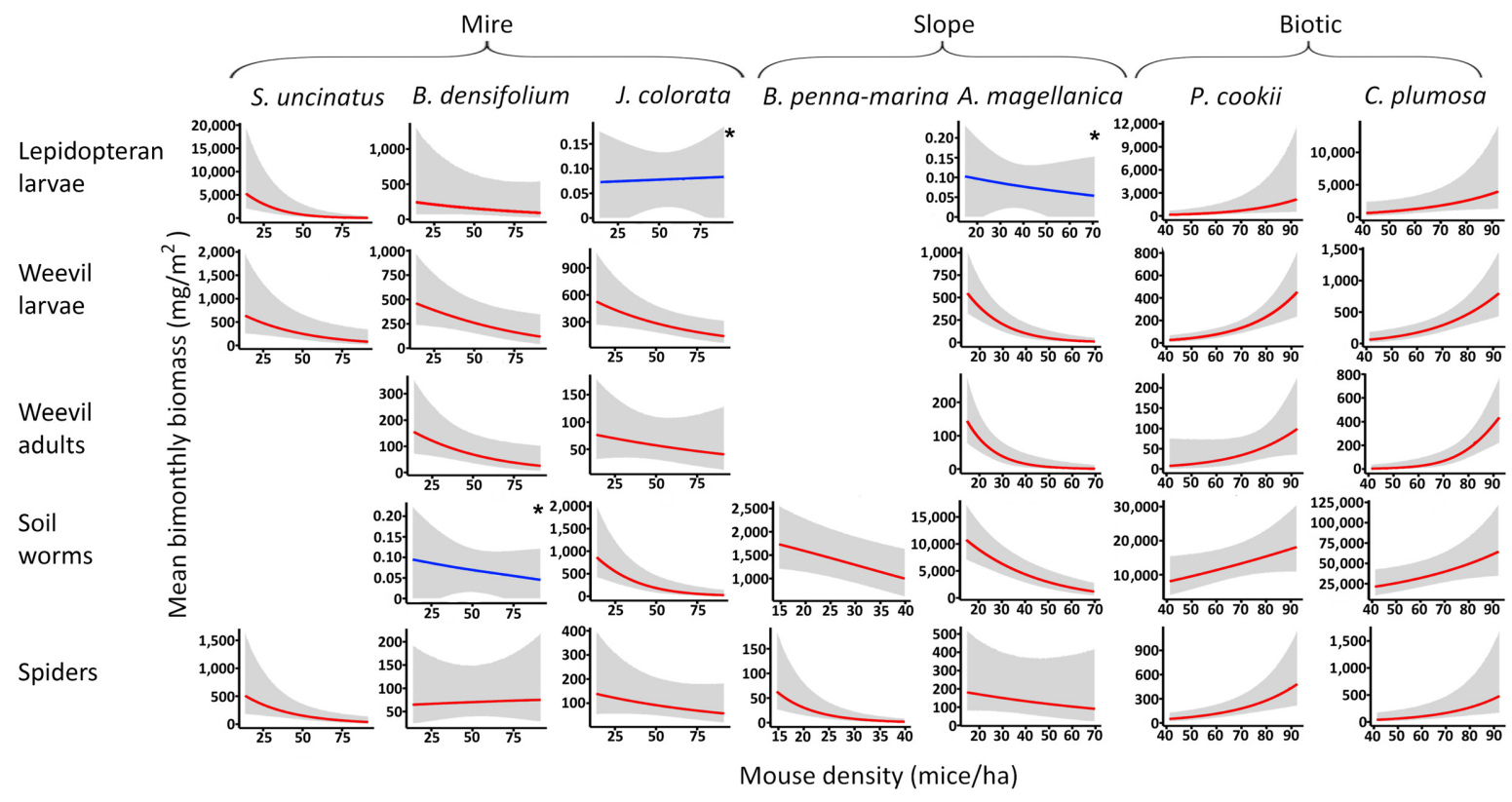

FIG. 4. Expected biomass of the five main invertebrate prey groups plotted against mouse density in the seven measured vegetation types on Marion Island. The shaded areas represent 95\% confidence intervals. Plots with blue lines and marked with a star represent the probability of presence only and are presented where too few invertebrate captures occurred to model biomass given presence. Blanks occur where too few captures occurred to model the probability of presence and/or biomass given presence with the exception of soil worms in $S$. uncinatus where the presence model failed due to linear separation. [Color figure can be viewed at wileyonlinelibrary.com]

mire habitats currently reach levels significantly greater than those experienced in 1979-1980 or the 1990s. The climate analysis makes clear that neither changes in temperature nor rainfall are directly driving this increase. Indeed, some of the highest mouse densities were observed in 2008-2009 despite being the two coldest years in the study period (Fig. 5a). Similarly, densities were higher in 1998 than in 1979, 1993, and 1996, despite being the wettest of those years (Fig. 5b). Rather, the observed shift toward an earlier breeding season was sufficient to explain the observed increase in mouse density, as demonstrated by the matrix model. An extended breeding season can have an especially profound effect on mouse density because it adds additional sexually mature cohorts to the population before the cessation of the breeding season (Berry 1968, Singleton et al. 2001, Mutze 2009). Because female mice on Marion Island reach sexual maturity at four months old (but as young as two months; Matthewson et al. 1994), earlier breeding initiation greatly increases the breeding population

TABLE 2. Estimated total number of mice present below $300 \mathrm{~m}$ above sea level in the mire, slope, and biotic habitats on Marion Island at peak density from 1979-1980 to 2008-2011.

\begin{tabular}{lccrr}
\hline \hline Year & Mire & Slope & Biotic & \multicolumn{1}{c}{ Total } \\
\hline $1979-1980$ & 122,500 & 121,730 & 87,990 & 332,220 \\
$1993-1994$ & 227,040 & 186,159 & 93,882 & 507,082 \\
$1998-1999$ & 430,274 & 185,179 & 82,214 & 697,216 \\
$2008-2011$ & 828,150 & 776,902 & 155,687 & $1,760,740$ \\
\hline
\end{tabular}

in the later breeding months. In turn, the total peak population is also greatly increased before the winter die-off. The importance of an extended breeding season in increasing density has been well-documented in other invasive house mouse populations (Pech et al. 1999, Singleton et al. 2001). Such phenological changes have, however, been almost exclusively linked to significant increases in food availability and quality (King 1983, Bomford 1987, Murphy 1992).

The observed advancement in the breeding season had a clear correlation with the number of precipitation-free nights during the winter season, which have increased by over $200 \%$ since the 1960 s (Fig. 5 c). The reproductive seasonality of house mice in cold climates, including Southern Ocean islands, is governed by the interaction between energy intake and the cost of thermoregulation (Bronson 1979, Manning and Bronson 1990) rather than photoperiod (Pryor and Bronson 1981). Because of their relatively high surface-to-volume ratio, mice are highly susceptible to heat loss and must commit a significant proportion of energy into maintaining homeostasis. This demand competes with the cost of reproduction, which is exceptional in rodents (Speakman 2008). For mice to extend their breeding season, a significant increase in energy intake, and/or decrease in the cost of thermoregulation must occur. Less frequent rainfall or snow-cover may allow mice to forage more proficiently and for longer periods, though the significant decline in invertebrate biomass on Marion Island may limit their ability to increase energy intake. 
a

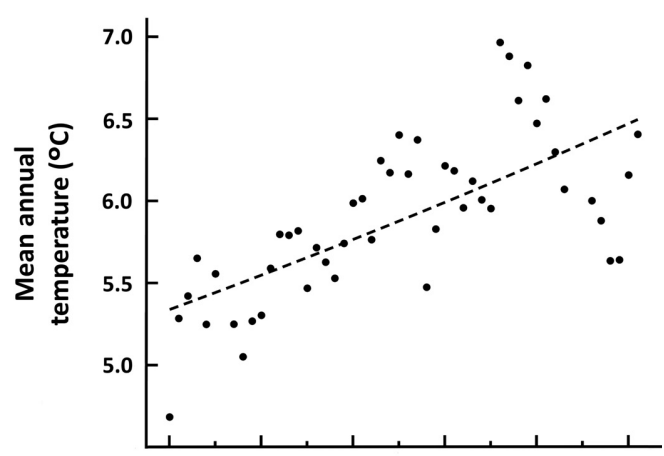

b

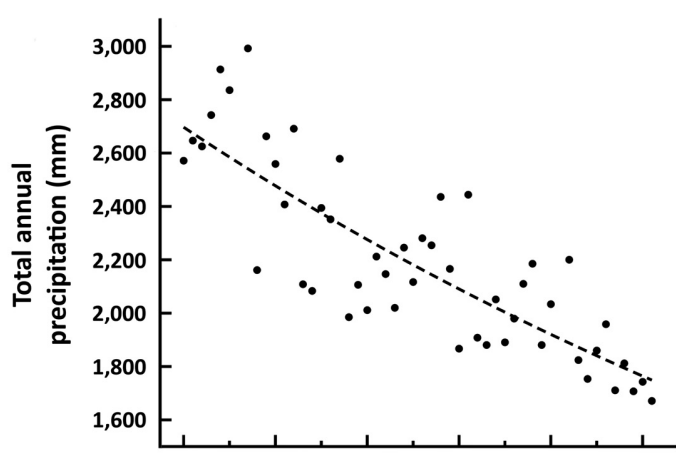

C

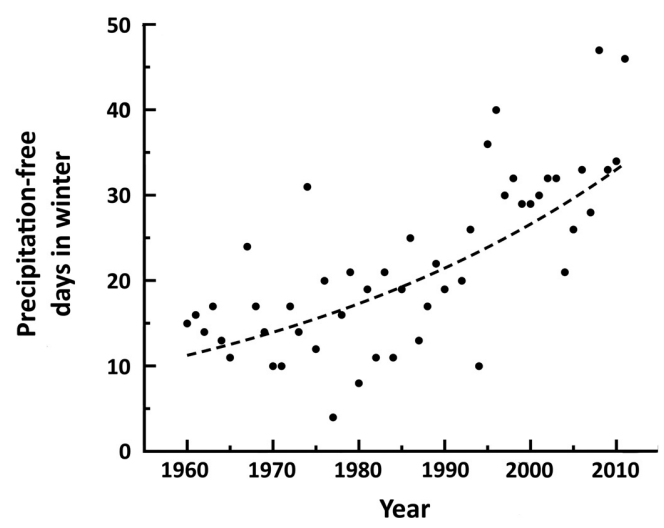

FIG. 5. Changes in (a) mean annual temperature, (b) total annual precipitation, and (c) number of precipitation-free days in winter (1 May to 30 September) on Marion Island, 19602011. An exponential least-squares curve has been fitted to the data in all three graphs.

Likely more significant is a decrease in the cost of thermoregulation. Under the low temperatures often encountered in the sub-Antarctic, missing a single meal can result in a total depletion of mouse fat stores (Bronson 1987). While Marion Island mice do cache seeds, such stores are typically small (Avenant and Smith 2003), and our trapping data confirm that mice forage nightly in all but the most inclement weather. Wetting reduces thermal resistance by half and leads to increased energy costs (Webb and King 1984), so fewer wet nights will significantly lessen the energetic costs of foraging, allowing mice to devote more energy toward reproduction.
While the matrix model demonstrated that an extension of the breeding season alone is capable of producing population increases similar to that observed on Marion Island, other demographic parameters such as survival, litter size, and age of sexual maturity are also likely to have changed. An additional consideration is the persistent drying of the island, as soil moisture content has significantly declined under a regime of increasingly lower precipitation (Chown and Smith 1993). This cumulative effect of climate change would not only contribute to lessening the energetic costs of mice while foraging, but also greatly improve the quality and quantity of available mouse burrows in previously marginal habitat (Avenant and Smith 2003, Ferreira et al. 2006). The present study could not, however, distinguish these possible additional changes. What is evident is that increased peak mouse densities are not the result of feral cat eradication in the 1980s (Bester et al. 2000). While cat removal may have contributed to mouse increases between 1979 and 1991, the eradication was all but complete prior to the 1991-1992 mouse trapping season (Bester et al. 2000), meaning that mice were without predation pressure from cats from this point onward. Although there may have been some lag in recovery of mice from any predation, previous work has suggested that cats had little impact on the mouse population (van Aarde 1980). Moreover, between 1977 and 1992 the cat population experienced rapid decline to zero as a consequence of an eradication program (Bester et al. 2000). Given this history and the rapid demographic responses by mice (Nathan et al. 2015), it seems unlikely that cat eradication had a large effect on the mouse population over the period of our study.

Despite enabling higher peak densities, ameliorating environmental conditions failed to lessen the extent of the May/June die-offs long observed in the Marion Island mouse population. Marion Island mice are not cold adapted (Webb et al. 1997) and the number of very cold wind-chill events has not changed over the past five decades (le Roux and McGeoch 2008). Additionally, while there has been a decline in the annual number of frost days (Huyser et al. 2000), warming is most pronounced in the austral summer months with winter months such as June showing the least change, while wind speeds have also increased. As a result, the number of very cold wind-chill events (based on the co-occurrence of extremes of wind speed and cold) has not changed (le Roux and McGeoch 2008). Seasonal invertebrate biomass also reaches its nadir at this time (Smith et al. 2002). Thus, mice still experience the same number of extreme winter cold events as in earlier decades, while both the seasonal and long-term decline in invertebrate biomass makes offsetting the increased cost of metabolism more difficult. As long as this continues to occur on Marion Island, die-offs can be expected.

There was a considerable shift in the importance of prey items in mouse diets between 1991-1992 and 20082011. Lepidopteran larvae continued to be the dominant 
TABLE 3. Estimated change in invertebrate biomass (mean \pm SD) in the mire, slope, and biotic habitats on Marion Island between 1976-1977 (baseline), 1996-1997, and 2006-2007.

\begin{tabular}{|c|c|c|c|c|c|c|}
\hline \multirow[b]{2}{*}{ Year } & \multicolumn{3}{|c|}{ Winter biomass change (kg/ha) } & \multicolumn{3}{|c|}{ Summer biomass change $(\mathrm{kg} / \mathrm{ha})$} \\
\hline & Mire & Slope & Biotic & Mire & Slope & Biotic \\
\hline 1976-1977 & $51.8 \pm 68.0$ & $49.3 \pm 26.6$ & $376.4 \pm 202.6$ & $83.4 \pm 107.0$ & $58.1 \pm 50.1$ & $305.2 \pm 106.9$ \\
\hline 1996-1997 & $6.1 \pm 5.9$ & $37.9 \pm 26.7$ & $167.9 \pm 83.8$ & $9.9 \pm 5.2$ & $60.7 \pm 59.4$ & $226.4 \pm 168.7$ \\
\hline 2006-2007 & $1.7 \pm 3.2$ & $16.4 \pm 21.7$ & $60.3 \pm 43.7$ & $2.3 \pm 2.1$ & $7.1 \pm 7.8$ & $52.4 \pm 23.4$ \\
\hline Loss from baseline & $96.7 \%$ & $66.8 \%$ & $84.0 \%$ & $97.3 \%$ & $87.7 \%$ & $82.8 \%$ \\
\hline
\end{tabular}

Note: Winter is May-October; summer is November-April.

prey item and increased in importance despite strong declines in biomass. This may be due to even greater losses in other prey items, specifically weevil adults, which appear to have declined to an extent where they no longer represent a significant portion of mouse diet. The decline in the importance of plant material may seem counterintuitive in view of invertebrate declines. However, it supports the idea that less frequent precipitation may allow mice to forage outside of burrows more frequently and efficiently, lessening mouse reliance on seed caches (van Aarde and Jackson 2007). If true, it presents another way in which climate change exacerbates the already considerable impacts of mice on invertebrates. Significant mouse-driven declines in preferred plant species such as the sedge Uncinia compacta (Smith and Steenkamp 1990, Chown and Smith 1993) may also play a role.

The two-part conditional models emphasized the importance of mouse density in influencing invertebrate biomass and demonstrated a predominantly negative relationship between predator and prey. The arrival of invasive mice on Marion Island predates the baseline data for invertebrate biomass by over 150 yr. Disregarding the likely detrimental impacts that occurred during this undocumented period, the changes in invertebrate biomass since the 1970s (Table 3) are exceptional. If the surface area occupied by each of the three studied habitats below $300 \mathrm{~m}$ is considered, the estimated total island invertebrate biomass loss is $86.1 \%$ and $89.8 \%$ in the winter and summer, respectively. This mouse-driven loss in biomass has profound implications for the Marion Island ecosystem. As the primary drivers of nutrient quality and primary productivity on the island, reductions in invertebrate biomass undoubtedly exacerbate nutrient limitation in an already impoverished system, with widespread effects on the entire terrestrial system (Smith and Steenkamp 1990, Treasure and Chown 2014). This includes prey switching from invertebrate predation to predation of seabirds such as albatrosses and petrels (Jones and Ryan 2010, Dilley et al. 2016a).

\section{Conclusions}

Mice have been introduced to at least 11 Southern Ocean islands (Angel et al. 2009) and a broad range of impacts have been reported (Wanless et al. 2009, St Clair
2011, Russell 2012, Eriksson and Eldridge 2014, Treasure and Chown 2014). However, long-term assessments of the region's mouse populations and their invertebrate prey are rare. The Marion Island data set provides a unique opportunity and confirms the long-held idea that ameliorating conditions brought on by climate change are capable of significantly increasing peak mouse populations, which in turn can suppress native invertebrate biomass. Just how this happens will require further work. The simultaneous increase in mouse populations and decline in invertebrate biomass suggests that mice must be utilizing other resources. The recent phenomena of mouse attacks on albatrosses (Jones and Ryan 2010), which has arisen independently around the island (Dilley et al. 2016a), as well as the limited post-cat eradication recovery of ground-nesting petrels (Dilley et al. 2016b), suggest that seabirds may be one such resource. While this study found a significant increase in the relative importance of avian tissue in mouse stomachs, sampling was designed for comparison with past work and did not specifically target seabird areas. A broader mouse diet program targeting areas where seabirds are more common could provide greater insight into their importance in mouse diet.

The current findings highlight the growing concern regarding the interaction between climate change and invasive species, though it should be noted that not all islands may be affected by climate change in a similar manner. For example, climate does not appear to constrain mice on Antipodes Island, one of the warmest and driest in the Southern Ocean (Weigelta et al. 2013), to the same extent as other islands (Elliott et al. 2015), and though trapping has been limited (Russell 2012), no increases have been suggested. Nevertheless, for systems where climate change is creating ameliorating conditions for mouse populations, the results of this study have farreaching implications. The current situation on Marion Island suggests that the severity of mouse impacts will increase, as even continued seasonal die-offs and significantly reduced foraging resources may not hold peak populations in check. Furthermore, these impacts are greatest when mice are the sole invasive mammal present on an island, a situation becoming more common as eradication efforts remove other alien predators but spare mice (Angel et al. 2009). From the perspective of conservation, it is vital that mice be given high priority when considering eradication for island restoration. 


\section{ACKNOWLEDGMENTS}

We thank all members of the Marion Island overwintering teams that contributed to the data collection and the South African National Antarctic Programme (SANAP) for logistic and funding support over many years. The South African Weather Service kindly provided weather data. The manuscript was greatly improved by two anonymous reviewers. This integrated study was funded by South African National Research Foundation (NRF) grant SNA2011110700005 to S. L. Chown and by a SANAP bursary to G. T. W. McClelland. R. Altwegg was supported by NRF grant no. 85802 .

\section{Literature Cited}

Angel, A., R. M. Wanless, and J. Cooper. 2009. Review of impacts of the introduced house mouse on islands in the Southern Ocean: are mice equivalent to rats? Biological Invasions 11:1743-1754.

Athens, J. S. 2009. Rattus exulans and the catastrophic disappearance of Hawai'i's native lowland forest. Biological Invasions 11:1489-1501.

Avenant, N. L., and V. R. Smith. 2003. The microenvironment of house mice on Marion Island (sub-Antarctic). Polar Biology 26:129-141.

Avenant, N. L., and V. R. Smith. 2004. Seasonal changes in age class structure and reproductive status of house mice on Marion Island (sub-Antarctic). Polar Biology 27:99-111.

Berry, R. J. 1968. The ecology of an island population of the house mouse. Journal of Animal Ecology 37:445-470.

Berry, R. J. 1970. The natural history of the house mouse. Field Study 3:219-262.

Berry, R. J., J. Peters, and R. J. van Aarde. 1978. Sub-antarctic House mice: colonization, survival and selection. Zoology 184:127-141.

Berry, R. J., W. N. Bonner, and J. Peters. 1979. Natural selection in house mice (Mus musculus) from South Georgia (South Atlantic Ocean). Journal of Zoology 189:385-398.

Bester, M. N., J. P. Bloomer, P. A. Bartlett, D. D. Muller, M. van Rooeyn, and H. Buchner. 2000. Final eradication of feral cats from sub-Antarctic Marion Island, southern Indian Ocean. South African Journal of Wildlife Research 30:53-57.

Bester, M. N., J. P. Bloomer, R. J. van Aarde, B. H. Erasmus, P. J. J. van Rensburg, J. D. Skinner, P. G. Howell, and T. W. Naude. 2002. A review of the successful eradication of feral cats from sub-Antarctic Marion Island, Southern Indian Ocean. South African Journal of Wildlife Research 32:65-73.

Blackburn, T. M., P. Cassey, R. P. Duncan, K. L. Evans, and K. J. Gaston. 2004. Avian extinction and mammalian introductions on oceanic islands. Science 305:1955-1958.

Bomford, M. 1987. Food and reproduction of wild house mice. 1. Diet and breeding seasons in various habitats on irrigated cereal farms in New South Wales. Australian Wildlife Research 14:183-196.

Borchers, D. L., and M. G. Efford. 2008. Spatially explicit maximum likelihood methods for capture-recapture studies. Biometrics 64:377-385.

Bronson, F. H. 1979. The reproductive ecology of the house mouse. Quarterly Review of Biology 54:265-299.

Bronson, F. H. 1987. Susceptibility of the fat reserves of mice to natural challenges. Journal of Comparative Physiology B 157:551-554.

Bronson, F. H. 2009. Climate change and seasonal reproduction in mammals. Philosophical Transactions of the Royal Society B 364:3331-3340.
Burger, A. E. 1978. Terrestrial invertebrates: a food resource for birds at Marion Island. South African Journal of Antarctic Research 8:87-99.

Burnham, K. P., and D. R. Anderson. 2002. Model selection and multimodel inference: a practical information-theoretic approach. Second edition. Springer, New York, New York, USA.

Burnham, K. P., and D. R. Anderson. 2004. Multimodel inference: understanding AIC and BIC in model selection. Sociological Methods and Research 33:261-304.

Caswell, H. 2001. Matrix population models. Second edition. Sinauer, Sunderland, Massachusetts, USA.

Chown, S. L., and V. R. Smith. 1993. Climate change and the short-term impact of feral house mice at the sub-Antarctic Prince Edward Islands. Oecologia 96:508-516.

Cooper, R. L., and J. D. Skinner. 1979. Importance of termites in the diet of the aardwolf Proteles cristatus in South Africa. South African Journal of Zoology 14:5-8.

Courchamp, F., J. Chapuis, and M. Pascal. 2003. Mammal invaders on islands: impact, control and control impact. Biological Reviews 78:347-383.

Crafford, J. E., and C. H. Scholtz. 1987. Quantitative differences between the insect faunas of Sub-Antarctic Marion and Prince Edward Islands: a result of human intervention? Biological Conservation 40:255-262.

de Villiers, M. S., J. Cooper, N. Carmichael, J. P. Glass, G. M. Liddle, E. Mcivor, T. Micol, and A. Roberts. 2006. Conservation management at Southern Ocean Islands: towards the development of best-practice guidelines. Polarforschung 75 : 113-131.

Deutsch, C. A., J. J. Tewksbury, R. B. Huey, K. S. Sheldon, C. K. Ghalambor, D. C. Haak, and P. R. Martin. 2008. Impacts of climate warming on terrestrial ectotherms across latitude. Proceedings of the National Academy of Sciences USA 105:6668-6672.

Dilley, B. J., S. Schoombiea, J. Schoombiea, P. G. Ryan, S. Schoombie, J. Schoombie, and P. G. Ryan. 2016a. "Scalping" of albatross fledglings by introduced mice spreads rapidly at Marion Island. Antarctic Science 28:73-80.

Dilley, B. J., M. Schramm, and P. G. Ryan. 2016b. Modest increases in densities of burrow-nesting petrels following the removal of cats (Felis catus) from Marion Island. Polar Biology 40:625-637.

Ebersole, J. P., and J. C. Wilson. 1980. Optimal foraging: the responses of Peromyscus leucopus to experimental changes in processing time and hunger. Ecology 46:80-85.

Efford, M. G. 2011. secr: spatially explicit capture-recapture models. R package version 2.2. http://cran.r-project.org/web/ packages/secr/index.html

Elliott, G., T. C. Greene, H. W. Nathan, and J. C. Russell. 2015. Winter bait uptake trials and related field work on Antipodes Island in preparation for mouse (Mus musculus) eradication. DOC Research and Development Series 345. Department of Conservation, Wellington, New Zealand.

Eriksson, B., and D. J. Eldridge. 2014. Surface destabilisation by the invasive burrowing engineer Mus musculus on a subAntarctic island. Geomorphology 223:61-66.

Ferreira, S. M., R. J. van Aarde, and T. D. Wassenaar. 2006. Demographic responses of house mice to density and temperature on sub-Antarctic Marion Island. Polar Biology 30:83-94.

Fletcher, D., D. MacKenzie, and E. Villouta. 2005. Modelling skewed data with many zeros: A simple approach combining ordinary and logistic regression. Environmental and Ecological Statistics 12:45-54.

Fordham, D. A., and B. W. Brook. 2008. Why tropical island endemics are acutely susceptible to global change. Biodiversity and Conservation 19:329-342. 
Frenot, Y., S. L. Chown, J. Whinam, P. M. Selkirk, P. Convey, M. Skotnicki, and D. M. Bergstrom. 2005. Biological invasions in the Antarctic: extent, impacts and implications. Biological Reviews 80:45-72.

Fukami, T., D. A. Wardle, P. J. Bellingham, C. P. H. Mulder, D. R. Towns, G. W. Yeates, K. I. Bonner, M. S. Durrett, M. N. Grant-Hoffman, and W. M. Williamson. 2006. Aboveand below-ground impacts of introduced predators in seabirddominated island ecosystems. Ecology Letters 9:1299-1307.

Gimenez, O., A. Viallefont, E. A. Catchpole, R. Choquet, and B. J. T. Morgan. 2004. Methods for investigating parameter redundancy. Animal Biodiversity and Conservation 27:1-12.

Gleeson, J. P. 1981. Ecology of the house mouse Mus musculus Linnaeus, on Marion Island. Thesis. University of Pretoria, Pretoria, South Africa.

Gremmen, N. J. M., and V. R. Smith. 2008. Terrestrial vegetation and dynamics. Pages 215-244 in S. L. Chown and P. W. Froneman, editors. The Prince Edward Islands: land-sea interactions in a changing ecosystem. Sun Press, Stellenbosch, South Africa.

Hanel, C. 1999. The distribution and abundance of macroinvertebrates in the major vegetation communities of Marion Island and the impact of alien species. Thesis. University of Pretoria, Pretoria, South Africa.

Haussmann, N. S., E. M. Rudolph, J. M. Kalwij, and T. McIntyre. 2013. Fur seal populations facilitate establishment of exotic vascular plants. Biological Conservation 162:33-40.

Honêk, A. 1996. Geographic variation in thermal requirements for insect development. European Journal of Entomology 93:303-312.

Huyser, O., P. G. Ryan, and J. Cooper. 2000. Changes in population size, habitat use and breeding biology of lesser sheathbills (Chionis minor) at Marion Island: impacts of cats, mice and climate change? Biological Conservation 92: 299-310.

Ingram, J. C., and T. P. Dawson. 2005. Climate change impacts and vegetation response on the island of Madagascar. Proceedings of the Royal Society A 363:55-59.

IPCC. 2013. Climate change 2013: the physical science basis. Pages 1535 in T. F. Stocker, D. Qing, G.-K. Plattner, M. Tignor, S. K. Allen, J. Boschung, A. Nauels, Y. Xia, V. Bex, and P. M. Midgley, editors. Contribution of working group 1 to the fifth assessment report of the intergovernmental panel on climate change. Cambridge University Press, Cambridge, UK.

Jones, M. G. W., and P. G. Ryan. 2010. Evidence of mouse attacks on albatross chicks on sub-Antarctic Marion Island. Antarctic Science 22:39-42.

Jones, H. P., B. R. Tershy, E. S. Zavaleta, D. A. Croll, B. S. Keitt, M. E. Finkelstein, and G. R. Howald. 2008. Severity of the effects of invasive rats on seabirds: a global review. Conservation Biology 22:16-26.

King, C. M. 1983. The relationship between beech (Nothofagus sp.) seedfall and populations of mice (Mus musculus), and the demographic and dietary responses of stoasts (Mustula erminea), in three New Zealand forests. Journal of Animal Ecology 52:141-166.

Kurle, C. M., D. A. Croll, and B. R. Tershy. 2008. Introduced rats indirectly change marine rocky intertidal communities from algae- to invertebrate-dominated. Proceedings of the National Academy of Sciences USA 105:3800-3804.

le Roux, P. C., and M. A. McGeoch. 2008. Changes in climate extremes, variability and signature on sub-Antarctic Marion Island. Climatic Change 86:309-329.

Lebreton, J., K. P. Burnham, J. Clobert, and D. R. Anderson. 1992. Modeling survival and testing biological hypotheses using marked animals - a unified approach with case studies. Ecological Monographs 62:67-118.
Manning, J. M., and F. H. Bronson. 1990. The effects of low temperature and food intake on ovulation in domestic mice. Physiological Zoology 63:938-948.

Matthewson, D. C., R. J. van Aarde, and J. D. Skinner. 1994. Population biology of house mice (Mus musculus L.) on subAntartic Marion Island. South African Journal of Zoology 29:99-106.

McCarthy, M. A., and P. I. P. Masters. 2005. Profiting from prior information in Bayesian analyses of ecological data. Journal of Applied Ecology 42:1012-1019.

Murphy, E. C. 1992. The effects of a natural increase in food supply on a wild population of house mice. New Zealand Journal of Ecology 16:33-40.

Mutze, G. J. 2009. Changes in body condition and body size affect breeding and recruitment in fluctuating house mouse populations in south-eastern Australia. Austral Ecology 34:278-293.

Nathan, H. W., M. N. Clout, J. W. B. MacKay, E. C. Murphy, and J. C. Russell. 2015. Experimental island invasion of house mice. Population Ecology 57:363-371.

Pech, R. P., G. M. Hood, G. R. Singleton, E. Salmon, R. I. Forrester, and P. R. Brown. 1999. Models for predicting plagues of house mice (Mus domesticus) in Australia. Pages 81-112 in G. R. Singleton, L. Hinds, H. Leirs, and Z. Zhang, editors. Ecologically-based rodent management. ACIAR, Canberra, Australian Capital Territory, Australia.

Perrigo, G. 1987. Breeding and feeding strategies in deer mice and house mice when females are challenged to work for their food. Animal Behaviour 35:1298-1316.

Plummer, M., A. Stukalov and M. Denwood. 2016. rjags: Bayesian graphical models using MCMC. R package version 4.6. https://CRAN.R-project.org/package=rjags

Pryor, S., and F. H. Bronson. 1981. Relative and combined effects of low temperature, poor diet, and short daylength on the productivity of wild house mice. Biology of Reproduction 25:734-743.

Pye, T., R. Swain, and R. D. Seppelt. 1999. Distribution and habitat use of the feral black rat (Rattus rattus) on subantarctic Macquarie Island. Journal of Zoology 247:429-438.

R Development Core Team. 2010. R: A language and environment for statistical computing. R Foundation for Statistical Computing, Vienna, Austria. http://www.r-project.org

Russell, J. C. 2012. Spatio-temporal patterns of introduced mice and invertebrates on Antipodes Island. Polar Biology 35:1187-1195.

Simberloff, D., et al. 2013. Impacts of biological invasions: what's what and the way forward. Trends in Ecology \& Evolution 28:58-66.

Singleton, G., C. J. Krebs, S. Davis, L. Chambers, and P. Brown. 2001. Reproductive changes in fluctuating house mouse populations in southeastern Australia. Proceedings of the Royal Society B 268:1741-1748.

Singleton, G. R., P. R. Brown, R. P. Pech, J. Jacob, G. J. Mutze, and C. J. Krebs. 2005. One hundred years of eruptions of house mice in Australia - a natural biological curio. Biological Journal of the Linnean Society 84:617-627.

Smith, V. R., and M. Steenkamp. 1990. Climatic change and its ecological implications at a Subantarctic island. Oecologia 85:14-24.

Smith, V. R., N. L. Avenant, and S. L. Chown. 2002. The diet and impact of house mice on a sub-Antarctic island. Polar Biology 25:703-715.

Speakman, J. R. 2008. The physiological costs of reproduction in small mammals. Philosophical Transactions of the Royal Society B 363:375-398.

St Clair, J. J. H. 2011. The impacts of invasive rodents on island invertebrates. Biological Conservation 144:68-81. 
Towns, D. R., I. A. E. Atkinson, and C. H. Daugherty. 2006. Have the harmful effects of introduced rats on islands been exaggerated? Biological Invasions 8:863-891.

Treasure, A. M., and S. L. Chown. 2014. Antagonistic effects of temperature change and biological invasion on ectotherm body size. Diversity and Distributions 20:202-213.

van Aarde, R. J. 1980. The diet and feeding behaviour of feral cats, Felis catus at Marion Island. South African Journal of Wildlife Research 10:123-128.

van Aarde, R. J., and T. P. Jackson. 2007. Food, reproduction and survival in mice on sub-Antarctic Marion Island. Polar Biology 30:503-511.

van Aarde, R. J., S. M. Ferreira, T. D. Wassenaar, and D. G. Erasmus. 1996. With the cats away the mice may play. South African Journal of Science 92:357-358.

Walther, G., et al. 2009. Alien species in a warmer world: risks and opportunities. Evolution 24:686-693.

Wanless, R. M., P. G. Ryan, R. Altwegg, A. Angel, J. Cooper, R. Cuthbert, and G. M. Hilton. 2009. From both sides: dire demographic consequences of carnivorous mice and longlining for the Critically Endangered Tristan albatrosses on Gough Island. Biological Conservation 142:1710-1718.

Watkins, B. P., and J. Cooper. 1986. Introduction, present status and control of alien species at the Prince Edward Islands, sub-Antarctic. South African Journal of Antarctic Research 16:86-94.

Webb, D. R., and J. R. King. 1984. Effects of wetting of insulation of bird and mammal coats. Journal of Thermal Biology 9:189-191.

Webb, P. I., G. T. H. Ellison, J. D. Skinner, and R. J. van Aarde. 1997. Are feral house mice from the sub-Antarctic adapted to cold? International Journal of Mammalian Biology 62:5862 .

Weigelta, P., W. Jetz, and H. Kreft. 2013. Bioclimatic and physical characterization of the world's islands. Proceedings of the National Academy of Sciences USA 110:15307-15312.

Welsh, A. H., R. B. Cunningham, C. F. Donnelly, and D. B. Lindenmayer. 1996. Modelling the abundance of rare species: statistical models for counts with extra zeros. Ecological Modelling 88:297-308.

\section{SUPPORTING INFORMATION}

Additional supporting information may be found online at: http://onlinelibrary.wiley.com/doi/10.1002/eap.1642/full

Data Availability

Data available from the Dryad Digital Repository: https://doi.org/10.5061/dryad.g36qr. 